\title{
The Internal and External Resource Integration in Operation Process: A Case Study
}

\author{
Lan Wang \\ School of Business, Beijing Language and Culture University, Beijing, China \\ Email:im2003@163.com
}

Received 26 February 2016; accepted 2 April 2016; published 6 April 2016

Copyright (c) 2016 by author and Scientific Research Publishing Inc.

This work is licensed under the Creative Commons Attribution International License (CC BY). http://creativecommons.org/licenses/by/4.0/

cc) (i) Open Access

\begin{abstract}
Currently, competitions among companies are not competitions between single companies, but are competitions between networks. Hence, it is very important for companies to know how to establish an effective external resource management and coordination mechanism. Company $\mathrm{A}$, has achieved the integration of resource in different industries and departments, integrating the resource of various levels to a large scale. Vertically, it integrated the regional and industry resource; horizontally, it integrated the resource from internal departments and related cooperative companies. This thesis analyzes different integration models in terms of resource integration provider, network services provider, innovation network. And furthermore we focus on Company A to reveal how to integrate internal and external recourses to achieve integration advantage.
\end{abstract}

\section{Keywords}

Internal Resource Integration, External Resource Integration, Integration Advantage

\section{Introduction}

Modern enterprise management emphasizes the realization of enterprise' overall performance. It refers to not only breaking the barriers between internal departments, but also eradicating the barriers between relative stakeholders such as companies, industries, and the government, leading to the comprehensive integration of the merchandise flow, the logistics flow, the information flow and the capital flow. Because of this, current competitions among companies are not competitions between single companies, but are competitions between net- 
works. Hence, it is very important for companies to know how to establish an effective external resource management and coordination mechanism. Company A, as a national company, has achieved the integration of resource in different industries and departments, integrating the resource of various levels to a large scale. Vertically, it integrated the regional and industry resource; horizontally, it integrated the resource from internal departments and related cooperative companies [1].

Under the incomplete information conditions, finding a business partner largely depends on the initial relationship between the company and other related companies. By settling at a local place and establishing the network of regional branches, a company can build a system of communication and cooperation, improving its technology innovation and competence. Company network is a value-added network of production [2]. Products, from the raw material to the final stage, add their market value by transferring in the company networks.

\section{Different Integration Models}

\subsection{Resource Integration Provider}

The change of competition concepts leads to the change of companies' resource constitution. Traditional resource division view claims that a company’s resource is mainly a company's interior resource, which is divided into three categories: primary resource, which refers to the products and services of a company; supportive resource, which refers to the supportive items and tools during the production of primary resource, including raw materials, equipment, capital and technology etc.; invisible resource, which refers to strategic plans and management controls. However, under the concept of competition, external resource such as the market and customers become important parts of companies’ resource and the main area in competitions. Meanwhile, resource providers are transferring from internal to external, which means that a company's resource might come from related members of related groups or companies, including internal organizations such as corporate shareholders, management crew, employees and stake holders, as well as external members such as the government, cooperators, competitors and the society etc. [3].

Therefore, company resource indicates all the items that can potentially or practically influence a company's value, including both the resource that a company can control and the resource that a company cannot control (e.g. external company resource). Clearly recognizing a company's core resource is the foundation of the effective utilization of resource to promote the company's innovation ability. Resource integration is to merge, classify and rearrange independent resource by need and come out with a more functional and effective resource system. The result of resource integration is to form a larger scale collection of items. The total effect and efficiency of the whole company is more remarkable than those of any single part in the company, and even more significant than the simple adding of every part. In conclusion, integration leads to overall efficiency and benefits [4].

\subsection{Network Services Provider}

By the measurement of capital stock and the complexity of problem decision, the business expansion ability is one of the most important strategies of a company. The decision of business ability requires that a company to distribute resource according to the future prediction. The strategic problem of business ability expansion is how to improve the business ability, approach the company's goal to add its market share, as well as avoiding the excess surpasses of business ability. Company A forms a multi-business mode of coal, electricity, road, harbor and chemistry, building its core competence and promoting its capital stock [5]. In this case, company A has a production services network based on coal, assisted and extended by other business parts.

The industry chain uses prospective, technologic and well-related companies and products as the core of the chain. These cores can connect the chain by technology and capital in all aspects. The industry chain is a new space organization that is based on the theories of the value chain, collecting related companies. The precondition of the emergence of the industry chain is the existence of a leading company with its core competence. By setting industry standards, sharing technology and resource, controlling core procedures, the leading company can organize and coordinate various relations, as well as establishing an industry chain. The leading company deals with businesses that it is good at, and cooperates with other companies on businesses that it is not good at or is not its core business, sharing the profits [6] [7]. 
The goal of the integration of the industry chain is to produce cooperative effect of companies in the chain. The constitution and collaboration of the industry value chain was based on the profits trading of products and services. On the contrary, in current days, the number of companies in the industry chain has increased and the companies are more professional [8] [9]. The coordination between companies gradually turns into deep collaboration such as strategic alliance, advantage compensation, resource sharing, process integration, and culture fusion.

\subsection{Innovation Network}

In the competition occupied by innovation, the flexibility requirements of an organization make its production more scattered. This organization type asks companies to have a friendly cooperation relationship [10]. There are some institutional methods that can avoid opportunism behaviors that might devastate collaboration and minimize market risks [11].

According to the principle of resource integration to self-innovation, companies should exert the promoting function of resource integration on their innovation increase from all aspects [12].

\section{The Realization of Integrated Advantages}

The business department of multi-business companies generates values by direct contacts with customers. Those companies compete for sales and profits in respective markets by meeting customers' needs. The business departments report to their parent companies and the headquarters, as well as the management group of the branches. Compare to the business department, the parent company has no customers or profits, but it has costs. The role of the parent company is an agency, connecting the business department and the capital providers and affecting the decision and strategies of the business department. Therefore, the business department generates the value, and it must realize the value created by the parent company. In conclusion, the challenge of the parent company is whether it can generate value to the business department [13].

The concept of competitive advantage offers goals, evaluating standards and testifying evidence for the business strategies. The concept of integrated company advantage plays the same role on the company's strategies: it provides a goal for the parent company. Even if the goal is not yet achieved, the parent company should work for it. The integrated company advantage also provides a measurement that can measure the specific behaviors for the parent company, pointing out the advantages and disadvantages. Meanwhile, the integrated company advantages provide a standard for the parent company that can testify the effectiveness of its strategies [13]. According to the standard, the parent company can ensure how can the current policies, directions, and actions increase its future integrated advantage.

The concept of the integrated advantage can and should be the core of decision making in all big companies. These decisions include the business combination and the management of the parent company. The integrated advantage emphasizes the matching characteristics of the parent company and the businesses in it. This correspondence can coordinate the interactions between business opportunities and the parent company. In this case, the parent company can achieve the goals and make profits. The parent company will concentrate on the business it has experience on and keep the correspondence. By the understanding of key factors in business departments, the parent company can reduce the risks from negative interferes (Graph 1).

The generation of money happens in business departments, and the lower business departments must realize the values created by the parent company. The challenge of the parent company is whether it can create values for the business department, i.e. creating integrated advantages. The condition of realizing the values is that there are opportunities that can improve the performance of the business combination, and the parent company can notice the opportunities as well as making most use of them. It is to say that the company's strategies must follow the parent company's businesses and match with these chances. The company must have some integrated characteristics that can allow the realization of these opportunities. The company must equip some specialized traits, including a mind map, a construction, a system, a procedure, the resource (talents) and technology, as long as these characteristics match with the opportunities and the company can create values. The company should not have those integrated characteristics that do not match with its businesses. Specifically, the decentralized contract of the company should not let the area that could damage the values interfere it, and the integration type must match with every business [14]. 


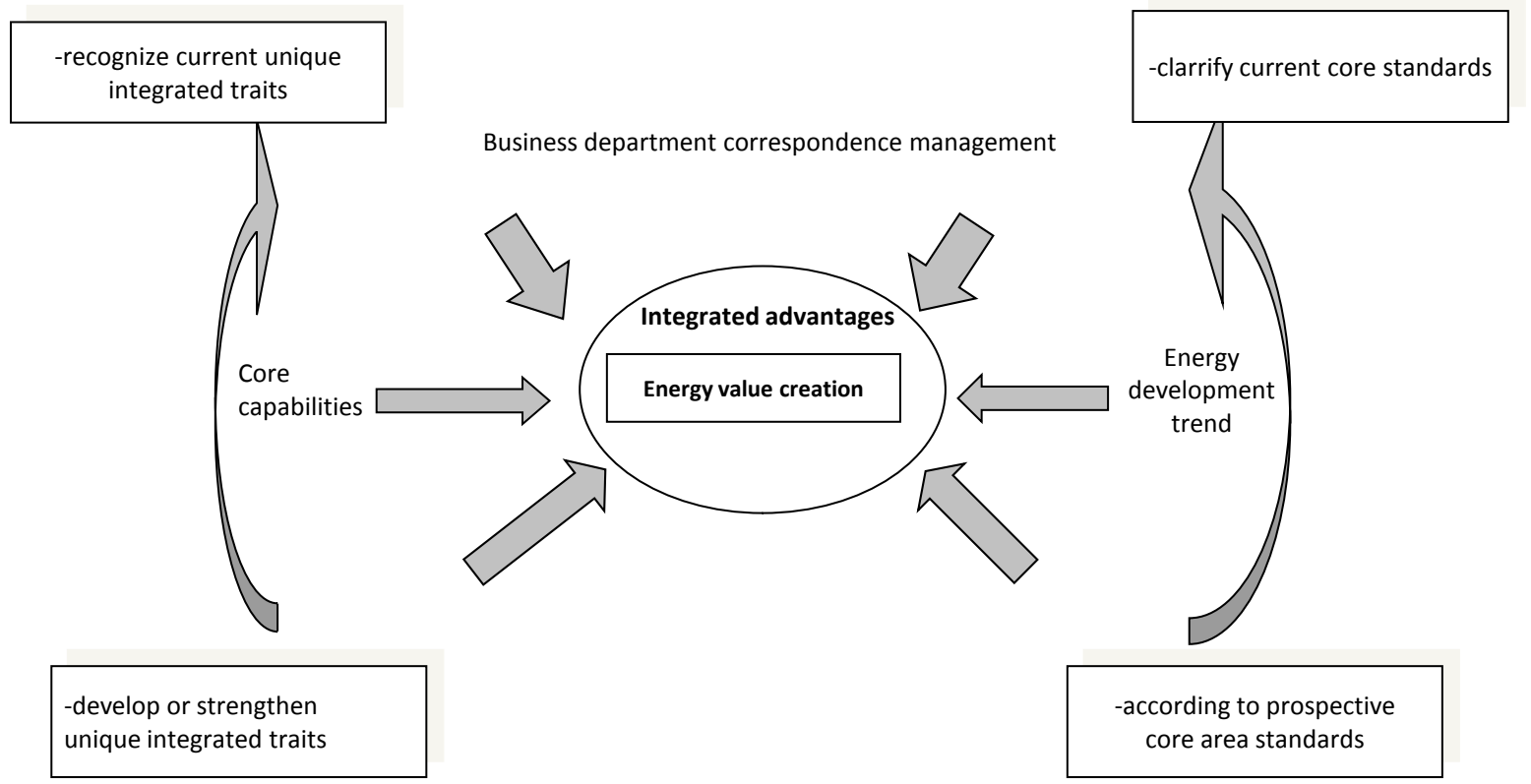

Graph 1. The multi strategy frame of company A on integrated advantages [12].

\section{Case Analysis}

\subsection{Company A's Network}

Company A is the leading state owned company of the coal industry, and its headquarter is set in Beijing. Company A is a large energy production and selling enterprise that is based on coal business and diversified in electric power, railway, harbor, shipping, coal to oil and coal chemical industry businesses. It is also the biggest coal company in China, as well as the biggest coal seller in the world. Company A mainly focuses on coal and other resource products, and controls the investments and management of electric power, heating power, harbor, railway, shipping, coal to oil and coal chemical industries. Company A was ranked the 165thin the 2014 annual Fortune Global 500.

Many parent companies believe that they can help business departments to think strategically and create values. They think that the business managers might ignore the long-term development of business departments and cannot consider about the key factors of success, or they have no broad horizons in planning. The strategic plans of parent companies are regarded as the solutions for these problems. However, incompetent managers will make the above mistakes, and capable business managers are less likely to make mistakes like their general managers. In fact, business managers understand the situation in the departments and they know more about the strategies and achievable long-term goals than their parent companies. This is why many business managers discover that the strategy plans of their parent companies are more of a burden than a source of profits. Nevertheless, some business departments gain profits from the cooperation with parent companies on strategy planning. Company A affects the speed and direction of business departments by strategy planning and evaluating. Company A, some institutions (coal operation research center, coal association) and consulting company (Mckinsey) made the Five-Year Plan and strategy planning jointly. They clearly evaluate which industries to enter and which industries not to enter (not or limited enter into industries they are not talented in), how big the electricity block is (25\%), which area to focus on in coal, power coal, coking coal industries, which railways and harbors to develop. Because of the effects caused by company A, the performance of independent business departments has improved.

Connection influence creates values through internal transactions, technology and resource sharing, product collection coordination or other mutual beneficial relationships. Parent companies encourage and manage the relationships among business departments to make the total value bigger than the simple adding of every part.

If a company has no parent company, it can still have connection influence with other companies. Only when parent companies create bigger values by connection influence than business departments do independently, the 
influence of parent companies is beneficial. Therefore, the key factor of connection influence is that parent companies can help to realize those connection opportunities that are ignored or avoided by business departments, or can improve the relationship of business departments.

Parent companies can encourage and require business departments to work closely. This phenomenon is called connection influence. Connection influence creates values through internal transactions, technology and resource sharing, product collection coordination or other mutual beneficial relationships. Connection influence exerts advantages in the following aspects: firstly, improves internal transactions; secondly, obtains benefits from coordination strategies (avoid useless competitions and unintended damages to win over competitors wisely); thirdly, connect powers versus outer groups (suppliers, employees/labor union, consumers, shareholders/bankers, the government, the pressure group); fourthly, a more proper utilization and exploitation of capitals (factories, equipment, buildings; logistics and sales equipment; sales group, function departments, sales departments; database, handouts, experts), fifthly, the proper use and discoveries of intangible capital (ideas, knowledge, talents, relations, reputation and brand).

There are many ways to affect the connection, including supplying policies, transferring pricing mechanism, cross department task groups, rewarding and evaluating system, work shifts, general policy or guidance, judging process, experts from headquarters, forums that encourage experience sharing and direct information exchange. Usual management procedures such as budgeting, strategy planning and capital expenses auditing are all related to the connection influence.

There are separated business departments at the center or node of the network. They cannot survive like external independent companies, so they are collected in a rectangular structure. For different goals, these departments can create various connections and obtain profits. Therefore, in order to create a closer entity, the parent company builds an organization upon those business departments that cannot live alone. This network needs more balance among cooperative relationships. The network also uses multi-dimensional connections to create more tension but not emphasizing on basic connections among other nodes.

Since the establishment of Chinese coal industry system in 1950s, the coal industry has been repeating the layout of point blocks-building a small but complete mining area surrounding the mine within several kilometers and sending products out by a short specialized line that is connected to the national railway. Since the coal belongs to bulk cargo transport, and the market is far from its production spot, the railway can be called the lifeline of coal industry. The condition of national railway transportation directly affects the profitability of the coal industry, forming a scene of "transportation decides sales". Therefore, the coal companies cannot control its own development, leading to a weak extension ability, an insufficient product scale, and a low company competitiveness.

On the contrary, company A creatively integrates coal related industries, forming a production services network based on coal, breaking the department separation and regional barrier under the market economy, eliminate the friction and internal consumption within industries, and keeping a continuous growth. At the same time of exploiting mining area, company A builds a 1300-kilometer self-operate railway and a harbor that takes in and out more than a hundred million, forming an integration of coal, road and harbor.

If the integration of coal, road, electricity, harbor and oil is the base of production, transportation and selling, then the connected sequence is the final result of integration. The connected sequence and integration are connected and cannot be separated. Integration is analyzed from the angle of the industry construction, and the connected sequence is a smooth system that is built in the production process. The connection of the industry emphasizes the relations of the upstream and the downstream, connecting the whole system completely and forming an integrated process of a supply chain that is developed by needs. Firstly, according to the market analysis predictions and the needs of consumers, the sales center makes sure the product types and quantities and provides orders for the mining area to collect products. Then, according to the regional distribution, product quantities and types needs of users, the sales center will make plans for products distribution, loading, transportation and harbor transferring, including the connecting point of the national railway, harbor quantities and directions etc. Lastly, the products are delivered to users timely at a guaranteed quality and quantity. The system controls the entire production, transportation and selling process. It is to say that the model of integration and the connected sequence accomplishes company A's status of being the leading coal company in China.

The business blocks in company A are mutually compensated and extended. Coal, road and harbor industries have made the production, transportation and selling happen in an entire process. Electricity and chemistry, as the extension of the industry chain, have realized the increase of coal business by coal-fired power generation, 
coal to oil, coal to olefin, forming the recycling economy of the integration of coal and electricity, and the integration of harbor and electricity. Under the general strategy frame of company A, coal, electricity, road, harbor and chemistry blocks have constituted a connection network. There are separated business departments at the center or node of the network. They cannot survive like external independent companies, so they are collected in a rectangular construction. For example, coal and electricity are closely connected through road and harbor. Company considers about purchasing regional electricity factories that ships can reach to when applying purchasing strategies, so the electricity factories have their own harbors, making sure the sufficient source of coal. Meanwhile, it directly provides coal to the electricity factories that are close to railway lines by train. The coal of Company A was underground three days ago, and can produce electricity after three days. Company A rarely has coal stocks, and the speed of transferring is very quick. Moreover, Company A uses a trackless layout, and the design of thousand tons mine strip mining integrates coal resource across regions. By exploiting mines of different regions together, the exploitation efficiency is improved and the land status is protected.

\subsection{Company A's Internal Integration}

Function and service influence refers to the roles played by function departments and service departments in company strategies. The scale, department constitution and the fee of staff of every company are different, but in most companies, the fee of staff usually accounts for a big part of companies' costs. Therefore these staff should make contributions to their parent companies. In evaluating the effects of staff, the function staff and service staff should be separated.

Basically, the reasonability of establishing strategic planning department in headquarters is to exert expertise and the economic values of utilization range. A certain function department of headquarter can use certain technologies or scale effects to the most, but business departments cannot do the same. Profession can make profits, and the function departments can obtain added values from profession and scale economy. This point offers convincing evidence for the existence of integrated advantages.

The finance, human resource, sales, engineer and technology departments offer specialized guidance to every business department, and help senior managers of parent companies to manage every business department or establish the connection influence between businesses. Except for bringing up with suggestions for the senior managers of parent companies, function staff might need to set the policy that every business department follows, think of suggestions for every business department as an excellent center, take part in the appointment and evaluation process of employees, and promote the communication of the best practice among business departments. By giving out the professional standards to business departments and helping them to set better function policies, function staff try to make values. The finance, human resource, sales, engineer and technology departments offer specialized guidance to every business department, and help senior managers of parent companies to manage every business department or establish the connection influence between businesses. Parent companies offer professional leading and cost-effective services to every business department by function and service influence. For example, the Railway Company applies "two-level management, three-level accounting": headquarter and branches are two-level management while headquarter, branches and work teams are three-level accounting. Headquarter is the profit center, mainly working on supervising, inspecting, guiding and offering services. Specifically, its responsibilities are strategy planning, industry development, resource distribution, capital operation, institution establishment and process controlling. Branches are cost centers, responsible for production safety, equipment maintenance and ensuring the complicity of work indicators. Work teams are centers of specialized technology and repairs. Headquarter have three branches. All the reimbursements go through the finance center and resource center. In this case, a two-level purchasing is built, and the company manages the purchasing center but is separated from three branches. This method realizes branches' cooperative purchasing, the sharing of public equipment, avoiding repeated investments and saving costs of purchasing and operation [15].

\subsection{Company A's External Integration}

Company A establishes a united technology exploitation of the innovation network by ways of commissioned development, united development, and commissioned audit with the help of universities, technology institutions and research groups. Company A also cooperates with international peers. It collects parts of the results from Japan, America and Germany's research in the project of direct liquefaction coal to gas, and comes up with new 
ideas. So far, it is applying for domestic and international patents.

Company A collaborates with matching factories and research on system technologies and related technologies jointly, making the products well produced by matching equipment and crafts. For example, the company signed research and develop contracts with Zhengzhou Coal Group and Beijing Coal Factory on 4.5 meter and 5.5 meter hydraulic support in the local development of high strength hydraulic support by special purchase. Many of the former research results are used in the manufacture of these two supports. At the same time, for dilemmas in the manufacturing of hydraulic supports, company A practices timely research and strongly supports the localization research of high strength hydraulic supports.

Universities and scientific institutions are research resources because these institutions are responsible for knowledge production, transferring and delivering, and they nurture innovative talents. The way of industryuniversity-research is the strong support of companies' innovation ability. Hence, company A cooperates with universities. For example, the joint creation of "S railway transportation integrated simulation training system" with the University is the most advanced simulation training system so far. This system realizes the standardization and automation of technologic employee trainings [15].

Innovative ideas can be aspired by the change of raw material, the change of consumers' needs, opportunities offered by new technology from universities and institutions and actions made by competitors. However, these information and knowledge are scattered before integration. In order to make the most use of the information, they should be integrated. While useless knowledge should be thrown away, valuable information should be integrated effectively in a systematic way. In the innovation network, company A can notice industry innovation timely and apply it in its own technology innovation. By the breaking innovation of crafts, related industries retain innovation and development. For example, Company A applies the development of equipment material industry in the coal industry innovation, extending the working surface from 150 meters to 360 - 400 meters, significantly improving the production efficiency and decreasing the costs and safety risks throughout the procedure.

Moreover, Company A uses the trackless layout and the design of strip mining of thousand tons mines. This design surpasses the textbook by ten years. Many of the economic technology indicators of Company A mining area are at the top of the world, and the operate models, idea, and the constant upgrading of equipment also promote the development of the world coal industry. It can be seen that the innovation ability of company A is from the establishment of innovation network. Meanwhile, as a source power, company A motivates the innovation of related industries and companies, being the engine of the social innovation network.

\subsection{Development Activities and Value Creation}

The focus of the company's development is the policy made by the main actor and force-the parent company. The parent company decides to develop which business, how these businesses are defined and how they are constituted. A company's development policy changes the definition, nature and quantity of business combinations. The decisions of merger (or separation) business are considered as the key of most companies' strategy choices. Merger and separation are usually very important in companies' development. Most of the parent companies emphasize its functions in big transactions. The risk investments of companies will also influence the constitution of their business combinations. Some parent companies emphasize that it is very important to promote company refreshing and new business building for their long-term stable development and vibration. Therefore, most of the parent companies regard company development decisions as the basic factor and an important source of value making

Specifically, since company A has a high efficiency in coal production and the recycle rate reaches $75 \%$, as well as focusing on the development of recycle economy and the establishment of clean energy channel, company A can exploit resource to the most and save the most energy, solving the national problem of a lack of energy. Moreover, every department of the company is connected to regional resource and it can make most use of the local resource policy, economic resource and human resource, building a harmonious relation with the local government. Company A contributes to the environment protection at the same time it pursues high production efficiency, and it motivates the development of local economy while it develops itself. Meanwhile, based on its long-term development strategy, company A integrates cross industrial resource efficiently, forming the circular economy of coal and electricity integration and harbor and electricity integration. Company A also builds its own railways, solving the bottleneck problem of exporting company A's coal. Company A also emphasizes the timeliness of innovation and it applies the innovation of other industries (for example, by using the 
innovation of the material industry, the company extents the design of its working surface of coal exploitation from 150 meters to 400 meters). On the other hand, every part of the businesses can maintain a sustainable relationship with related upstream and downstream companies (for example, the supplier of coal machine is integrated with the research and design of equipment production), forming an effective supplier coordination mechanism, and building a supplier certification system that can strongly support company A's production style and technology innovation [15].

Moreover, company A obtains resource by purchasing private companies that operate well to expand its business. For example, A purchased to integrate the coking coal companies and resource around $\mathrm{Z}$ area. This is the biggest domestic merger of a private company in recent years, and the total capital was more than 2 billion. By mutual advantage compensation of the national company and the private company, completely using the current resource and equipment as well as using company A's capital, operation and market advantages to overcome bottleneck problems of capital, operation and market, this merger went on smoothly in one year of operation. Last year, the company paid regional tax of 45 million RMB, its profit was 10 million RMB, and employees' payments increased more than $30 \%$.

\section{Conclusion}

Parent companies create new business by merging or selling its business. Meanwhile, it is very important to promote company refreshing and new business building for their long-term stable development and vibration. "The advantage of integration" is making more values than other companies, and it also includes the meaning of merging businesses. In order to create more values than other parent companies, the company has to obtain advantages that surpass other parent companies. These advantages can come from the discovery of opportunities that the performance is improved, and from the strong capability that can make the opportunities come true. If a business department creates more values than its competitors, then it obtains competitive advantages. It can be found how its competition strategies surpass its competitors by analyzing a company's source of competition. Similarly, if a parent company creates more values than its competitors, it obtains integrated advantage. The integrated advantage is the standard and basis of a company's strategies, and it decides the goals of the parent company and its business combination, as well as evaluates these decisions.

\section{Acknowledgements}

This research is supported by BLCU (Beijing Language and Culture University) supported project (supported by the Fundamental Research Funds for the Central Universities) (Approval Number: 16YJ04002); Humanity and Social Science Foundation of Ministry of Education of China (Project No.15YJC630123); Beijing Supporting Central University Joint Project—Young Talent Plan (Project No. YETP0880).

\section{References}

[1] Krackhard, D. (1992) The Strength of Strong Ties: The Importance of Philos in Organizations. In: Nohria, N. and Eccles, R., Networks and Organizations: Structure, Form and Action, Harvard University Press, Boston.

[2] Lane, P.J. and Lubatkin, M. (1998) Relative Absorptive Capacity and Inter-Organizational Learning. Strategic Management Journal, 19, 461-477. http://dx.doi.org/10.1002/(SICI)1097-0266(199805)19:5<461::AID-SMJ953>3.0.CO;2-L

[3] Langerak, F. (2003) An Appraisal of Research on the Predictive Power of Market Orientation. European Management Journal, 21, 447-464.

[4] Kale, P., Singh, H. and Perlmutter, H. (2000) Learning and Protection of Proprietary Assets in Strategic Alliances: Building Relational Capital. Strategic Management Journal, 21, 217-237. http://dx.doi.org/10.1016/S0263-2373(03)00073-2

[5] Kanter, R.M. (1988) When a Thousand Flowers Bloom: Structural, Collective, and Social Conditions for Innovation in Organization. Research in Organizational Behavior, 10, 169-211. http://dx.doi.org/10.1002/(SICI)1097-0266(200003)21:3<217::AID-SMJ95>3.0.CO;2-Y

[6] Henderson, R. and Clark, K. (1990) Architectural Innovation: The Reconfiguration of Existing Product Technologies and the Failure of Established Firms. Administrative Science Quarterly, 35, 9-30. http://dx.doi.org/10.2307/2393549

[7] Hipkinand, I. and Naude, P. (2006) Developing Effective Alliance Partnerships: Lessons from a Case Study. Long Range Planning, 39, 51-69. http://dx.doi.org/10.1016/j.lrp.2005.09.003 
[8] Holmqvist, M. (2003) A Dynamic Model of Intra- and Interorganizational Learning. Organization Studies, 24, 95-103. http://dx.doi.org/10.1177/0170840603024001684

[9] Gulati, R. and Singh, H. (1998) The Architecture of Cooperation: Managing Coordination Costs and Appropriation Concerns in Strategic Alliances. Administrative Science Quarterly, 43, 781-814. http://dx.doi.org/10.2307/2393616

[10] Kazadi, K., Lievens, A. and Mahr, D. (2016) Stakeholder Co-Creation during the Innovation Process: Identifying Capabilities for Knowledge Creation among Multiple Stakeholders. Journal of Business Research, 69, 525-540.

[11] Ouchi, W.G. (1979) A Conceptual Framework for the Design of Organizational Control Mechanisms. Management Science, 25, 833-848. http://dx.doi.org/10.1287/mnsc.25.9.833

[12] Goold, M., Campbell, A. and Alexxander, M. (2004) Corporate Level Strategy (Translator: Huang Y.Y.). Posts and Telecom Press, Beijing. (In Chinese)

[13] Chang, J.-J., Hung, K.-P. and Lin, M.-J.J. (2014) Knowledge Creation and New Product Performance: The Role of Creativity. R\&D Management, 44, 107-123.

[14] Renmin Research Group (2008) Shenhua Model and the Implication for National Economy Reformation. Research report, Beijing.

[15] Padula, G. (2008) Enhancing the Innovation Performance of Firms by Balancing Cohesiveness and Bridging Ties. Long Range Planning, 41, 395-419. http://dx.doi.org/10.1016/j.lrp.2008.01.004 